\title{
UTILITARIAN AND HEDONIC VALUES THAT INFLUENCE CUSTOMER SATISFACTION AND THEIR IMPACT ON THE REPURCHASE INTENTION: ONLINE SURVEY TOWARDS BERRYBENKA FASHION E-COMMERCE'S BUYER
}

\author{
Johar Diah Syafita*, Suharyono, Sunarti \\ Faculty of Administrative Science, University of Brawijaya, Indonesia \\ *E-mail: syafitatajohar@gmail.com
}

\begin{abstract}
This research aims to describe the influence of utilitarian and hedonic values toward customer satisfaction and repurchase intentions. The sampling method used for research is purposive sampling with 141 respondents who bought Berrybenka products. Based on the Structural Equation Modeling, it is found that utilitarian and hedonic values are significant towards repurchase intention through customer satisfaction.
\end{abstract}

\section{KEY WORDS}

Utilitarian value, hedonic value, customer, satisfaction, repurchase intention, e-Commerce.

One of the ways of needs fulfillment is going shopping. Grocery shopping is Indonesian citizen behavior. Individual's motivation to go shopping is different. According to Babin et al., (2000) motivational value why people go shopping is divided into two, i.e. utility and hedonic value. Value means a number of tangible or intangible good benefit, and perceived cost by a customer (Kotler and Keller, 2009:14). An individual who goes shopping based on the utility motivation will seek the utilitarian benefits from the product like the ease of use or product efficiency, while the one who goes shopping based on the hedonic motivation will search for hedonic benefits like the convenience of product selection process and entertainment obtained during going shopping. Based on the research result of techinasia.com, $69 \%$ motivation of Indonesian society to monthly go shopping comes from utilitarian shopping value in which they go shopping based on their needs, the product they search for and want. While $61 \%$ Indonesia citizen motivation to go shopping comes from hedonic shopping value, in which the consumer goes shopping because of it is able to bring happiness and forget the problem they face and relieve fatigue so that able to make them better (swa.co.id).

Motivation coming from the utility or hedonic value will simultaneously influence satisfaction. According to the Moon's (2016) research, utilitarian shopping value and hedonic shopping value has a positive influence on the customer satisfaction. Customer satisfaction is the sense of happiness or disappointed felt by someone since comparing perceived performance by product towards their expectation (Kotler and Keller, 2009). Customer will conduct an evaluation by comparing product performance that has been consumed or used with customer expectation. One of the impacts of satisfaction is repurchase intention. According to Jakada's (2016) research, customer satisfaction brings a positive influence on the repurchase intention. After the individual feels satisfaction, there will be reactions from consumer like talking about that $\mathrm{s} / \mathrm{he}$ is satisfied, having repurchase intention, and recommending to other people that would be word-of-mouth.

Repurchase intention is a subjective possibility in which customer will continuously buy a product from the seller. This repurchase intention is commonly conducted by those who feel satisfied with the service given. After they feel satisfied there will be reactions from consumer like talking that they are satisfied, having repurchase intention, and recommending to other people that will be word-of-mouth.

Needs fulfillment of Indonesian citizen is various from the needs of insight, clothing, and etc. In accordance with survey conducted by techinasia.com (2013), it explains Indonesian citizen from the needs for book by $1.8 \%$, cosmetic by $2.3 \%$, accessories of hand phone by $2.8 \%$, car accessories by $3 \%$, handphone and plane ticket by $5.1 \%$, wristwatch by $7.6 \%$, bag by $20.2 \%$, shoes by $20.2 \%$ and the most stuff needed by Indonesian citizen is 
apparel by $61.7 \%$ bought through online shopping. Being seen from the total, Indonesian citizen puts their big needs on apparel.

Talking about the needs for apparel, nowadays, there are so many fashion retail shops in Indonesia. One of them is fashion e-commerce in which the trading is conducted by online through an electronic system like the internet, www, and etc. In accordance with the survey conducted by CNN Indonesia, E-commerce transaction in Indonesia was estimated reach up to Rp394.000.000.000 in 2016 (cnnindonesia.com). One of the fashion e-commerce in Indonesia is Berrybenka. It is a specialty online shopping site of fashion and beauty in Indonesia. Berrybenka sells more than 1000 local and international brand including in-house product label. Berrybenka itself sells product by online through website, application, and also provides physical store in several cities in Indonesia. One of the Berrybenka superiorities that are not owned by other e-commerce is providing a new system called Cash on delivery (COD) 2.0. This new system allows the customer to choose and pay the stuff or do the transaction through the website and take it to the nearest physical store. In addition, the customer is also permitted to choose the stuff they want without having to take all things ordered previously through the website in which this system truly eases and gives an advantage to the consumer.

\section{LITERATURE REVIEW}

Consumer Behavior. Consumer behavior discusses more the involvement of process when individuals or groups choose, buy, use or decide product, service, idea or experience to satisfy the needs and wants (Solomo 2013:31). Consumer behavior is the act involving consumer to find, buy, use, evaluate, and spend product and service they expect will satisfy them (Sangadji and Sophiah 2013:8). The stages that can be described based on the definition of consumer behavior are (1) the stage to feel there are needs and wants, (2) effort to get product, find information about product, price, and distribution channel, (3) consumption, usage, and evaluation of product after being used, (4) and post-purchase action in form of either satisfied or not.

Motivation and Customer Value. Value reflects a number of tangible or intangible benefit and perceived value by the customer (Kotler, Keller 2009:14). Definition of Consumer value according to Holbrok (2006) is an interactive relativistic preference experience. It means the interaction happens between the object (product) and subject (customer). The interaction between this object and subject is influenced by three senses which are comparative, personal and situational. The definition of sense, according to Solomon (2013:70) is a sensation directed toward spontaneous respond of sensor receiver within an individual like (eye, ear, nose, mouth, and fingers, skin) that will stimulate light, color, sound, texture and etc. According to Solomon (2002:102), motivation is a process influencing someone to act. It appears when there are needs to be fulfilled. Following is the explanation of the type of needs according to Solomon (2002:104).

- Biogenesis needs: needs for several important elements to live like water, food, air, etc;

- Psychogenic needs: needs obtained during the process of becoming a member of a culture like status, power, recognition, etc;

- Utilitarian needs: needs that stress on the object, tangible attributes of a product like a calorie contained within the food that will be consumed, quality of apparel product;

- Hedonic needs: experimental and subjective needs like enjoyment and self-reliance. etc.

Customer Satisfaction. According to Kotler Keller (2009), satisfaction is the sense of happiness or disappointment raising since comparing perceived performance toward their expectation. Satisfaction relates to the feeling and expectation when someone hopes or expects something and the result is same as the expected. According to Sumarwan in Sudaryono (2016), it is said that satisfaction and dissatisfaction is the result of evaluation from an experience of using or consuming product or service. The expectancy disconfirmation model is a model explaining the process of consumer satisfaction and 
dissatisfaction formation, which is the impact of consumer expectation comparison before the buying or the real consumption with performance gained by the consumer. The result of the comparison is then grouped into disconfirmation and confirmation:

- Positive disconfirmation happens when the actual performance is bigger than consumer performance expectation.

- Simple confirmation happens when the actual performance is actually same as the expectation.

- Negative disconfirmation happens when the actual performance is smaller than consumer expectation.

Repurchase intention. Post-purchase behavior happens after the process of decision, the consumer will not stop until the process of consumption. The consumer will do an evaluation of the consumption conducted. This is called post-purchase alternatives evaluation for post-consumption. Post-purchase behavior, According to Kotler and Keller (2012), is divided into three types:

- Post-purchase satisfaction. Satisfaction is a function that is truly close to between expectation and product performance. If the performance is far from customer expectation so that they will be disappointed, but if fulfilling the expectation the customer will be satisfied and if beyond the expectation customer will be happy.

- Post-purchase Action. The satisfied consumer is a consumer who purchases again the product and also will talk good thing to another customer, while not satisfied consumer will ignore or return the product, they may find information stating higher value or make a public action by complaining to the company. One of the ways of post-purchase is doing repeat purchase.

\section{METHODS OF RESEARCH}

This was explanatory research aiming to explain the causal relationship between the variable to test the hypothesis (Singarimbun, 2014:5). This research was conducted at Berrybenka website (Berrybenka.com) with purposive sampling technique. The type of scale used was Likert scale with internet survey method. The population of this research was all buyers of Berrybenka product through the website as the end-user in Indonesia. It was tested to 141 respondents. Sample characteristics of this research were as follow:

- Arranging an online questionnaire using Google form;

- Questionnaire would be in form of link https://goo.gl/forms/6Mlo26NaVIvxptfb2;

- The researchers collected sample from several social media, firstly is Instagram, by writing \#berrybenkalook2017 on the search column and collecting user who uploaded a picture wearing Berrybenka product. The respondents filling this form are at least $18+$ years old;

- After collecting sample from Instagram, the next social media used was twitter by going to the profile of @Berrybenka.com and then collecting user interacting with @Berrybenka.com account through tweets and reply;

- Another way to do is spreading link through timeline of Line and Whatsapp.

\section{RESULTS AND DISCUSSION}

The result of Goodness of Fit test indicates that there are no criteria that can represent Goodness of Fit, so it is conducted model modification by considering a recommendation from modification indices.

This part relates to the evaluation of coefficients or parameters indicating a causal relationship or the influence of one latent variable to another. The causal relationship is not significant if critical ratio value (C.R.) is in the range of -1.96 and 1.96 with a significance level of 0.05 . Through the help of AMOS 20 program application is gained value estimation result of ratio model structural. The result of the calculation of those coefficients is shortly presented in table 5.25 . 
Table 1 - Model Goodness of Fit Evaluation

\begin{tabular}{|c|c|c|c|}
\hline Goodness of Fit Index & Cut of value & Result & Description \\
\hline Chi-Square / CMIN & $\begin{array}{l}\text { < Chi-Table: Good fit } \\
\text { > Chi-Table: Poor fit }\end{array}$ & 82,212 & Model Poor Fit \\
\hline P-value CMIN & $\begin{array}{l}>0,050: \text { Good fit } \\
<0,050: \text { Poor fit }\end{array}$ & 0,001 & Model Poor Fit \\
\hline CMIN/DF & $\begin{array}{l}<\text { 2,000: Good Fit } \\
<3,000: \text { Marginal Fit } \\
\text { > 3,000: Poor Fit }\end{array}$ & 1,787 & Model Good fit \\
\hline RMSEA & $\begin{array}{c}<0,080: \text { Good fit } \\
<0,100: \text { Marginal Fit } \\
\quad>0,100: \text { Poor fit }\end{array}$ & 0,075 & Model Good fit \\
\hline GFI & \multirow{4}{*}{$\begin{array}{l}>\text { 0,900: Good fit } \\
>0,800: \text { Marginal fit } \\
\quad<0,800: \text { Poor fit }\end{array}$} & 0,908 & Model Good fit \\
\hline AGFI & & 0,843 & Model Marginal fit \\
\hline TLI & & 0,95 & Model Good fit \\
\hline CFI & & 0,965 & Model Good fit \\
\hline
\end{tabular}

Table 2 - Hypothesis Test Result

\begin{tabular}{|c|c|c|c|c|c|c|}
\hline \multicolumn{3}{|c|}{ Variable } & \multirow{2}{*}{ Path Coefficient } & \multicolumn{2}{|c|}{ Hypothesis Test Result } & \multirow{2}{*}{ Conclusion } \\
\hline Exogenous & $-->$ & Endogenous & & $\mathrm{CR}$ & $p$-value & \\
\hline Utilitarian Value (X1) & $-->$ & Customer Satisfaction (Z) & 0,585 & 4,751 & 0,000 & Significant \\
\hline Hedonic Value (X2) & $-->$ & Customer Satisfaction (Z) & 0,349 & 3,17 & 0,002 & Significant \\
\hline Utilitarian Value (X1) & $-->$ & Repurchase Intention (Y) & 0,016 & 0,119 & 0,905 & Not Significant \\
\hline Hedonic Value (X2) & $-->$ & Repurchase Intention (Y) & 0,092 & 0,881 & 0,378 & Not Significant \\
\hline Customer Satisfaction (Z) & $-->$ & Repurchase Intention (Y) & 0,869 & 5,454 & 0,000 & Significant \\
\hline
\end{tabular}

Table 2 indicates estimation result and hypothesis test. Utilitarian value variable (X1) has Path Coefficient influence over the Customer Satisfaction $(Z)$ by 0.585 with $C R$ value by 4.751 and $p$-value by 0.000 . Becuase $p$-value is $<0.05$, the statistical hypothesis states that $\mathrm{Ho}$ is rejected which means that hypothesis one $(\mathrm{H} 1)$ stating that utilitarian value has a significant influence on the customer satisfaction is accepted.

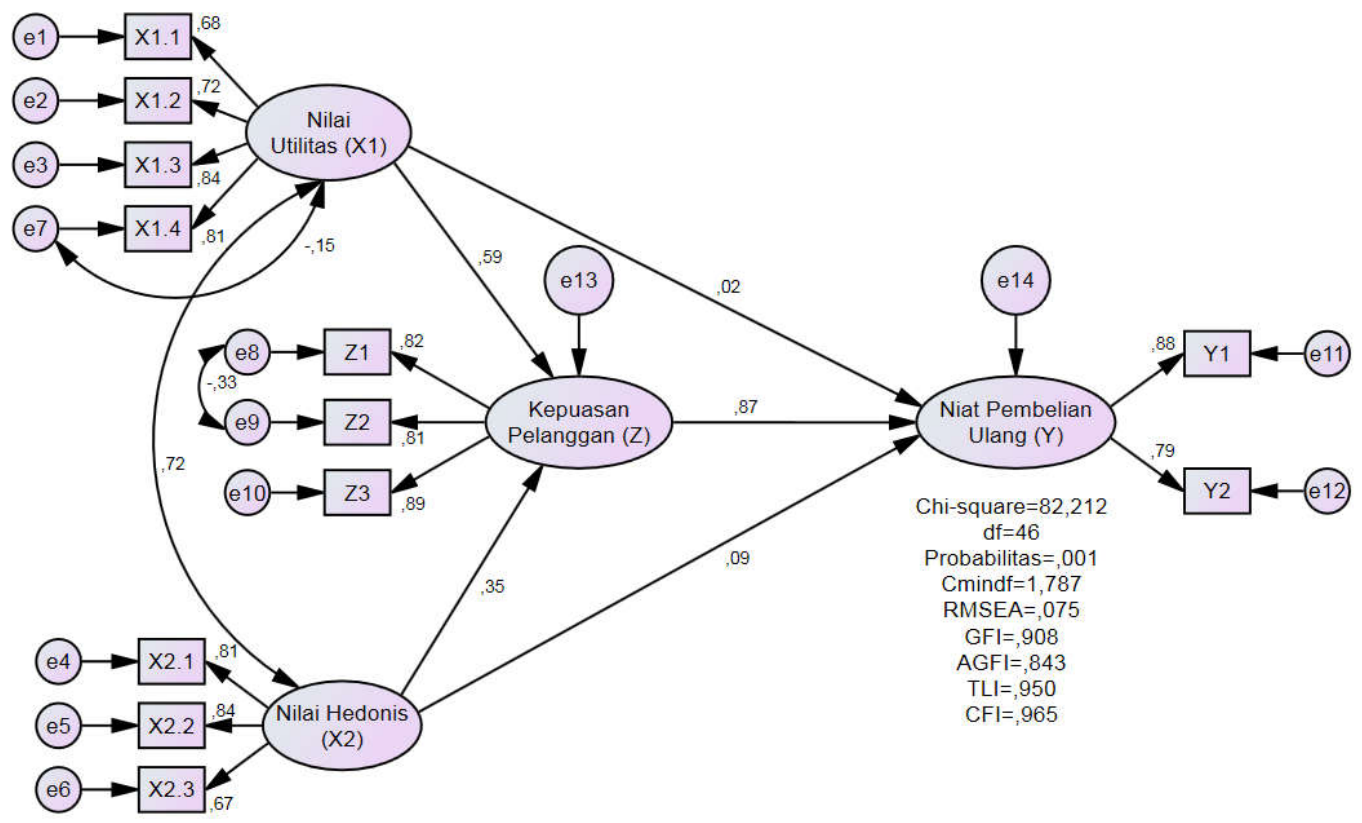

Figure 1 - Post-Modification Outer Model Chart (CFA) and Structural Model

Hedonic Value Variable (X2) has Path Coefficient influence over the Customer Satisfaction $(Z)$ by 0.349 with $C R$ value by 3.17 and $p$-value by 0.002 . Becuase $p$-value is < 0.05 , the statistical hypothesis states that $\mathrm{Ho}$ is rejected which means that hypothesis three $(\mathrm{H} 3)$ stating that hedonic value (X2) has a positive influence over the customer satisfaction $(Z)$ is accepted. 
Utilitarian Value Variable (X1) has Path Coefficient influence over the Repurchase Intention (Y) by 0.016 with $C R$ value by 0.119 and $p$-value by 0.905 . Becuase $p$-value is < 0.05 , the statistical hypothesis states that Ho is accepted which means that hypothesis two $(\mathrm{H} 2)$ stating that utilitarian value $(\mathrm{X} 1)$ has a positive but not significant influence over the repurchase intention $(\mathrm{Y})$ is rejected.

Hedonic Value Variable (X2) has Coefficient Path influence over the Repurchase Intention $(Y)$ by 0.092 with $C R$ value by 0.881 and $p$-value by 0.378 . Becuase $p$-value is $>$ 0.05 , statistical hypothesis states that $\mathrm{Ho}$ is rejected which means that hypothesis four $(\mathrm{H} 4)$ stating that Hedonic Value (X2) has a positive but not significant influence over the Repurchase Intention is rejected.

Customer Satisfaction Variable $(Z)$ has path coefficient influence over the Repurchase Intention $(Y)$ by 0.869 with $C R$ value by 5.454 and $p$-value by 0.000 . Becuase $p$-value is < 0.05 , the statistical hypothesis states that $\mathrm{Ho}$ is rejected which means that hypothesis five (H5) stating that Customer Satisfaction has a significant influence on the customer satisfaction is accepted. In order to ease outer model evaluation and also integrated with path analysis, it is provided outer model chart assessment and structural model as demonstrated in figure 1.

\section{CONCLUSION}

According to the stated problem, analysis result and hypothesis from the previous chapter so that the conclusions are as follows:

1. Utilitarian Value Variable (X1) has a significant influence on the Customer Satisfaction (Z) with estimation value by $58.5 \%$ and $p$-value by 0.000 with positive direction.

2. Hedonic Value Variable (X2) has a significant influnce over the Customer Satisfaction (Y) with estimation value by $34.9 \%$ and $p$-value by 0.002 with positive direction.

3. Utilitarian Value Variable (X1) has a not significant influence over the Repurchase Intention $(Z)$ with estimation value by $0.16 \%$ and $p$-value by 0.905 with positive direction.

4. Utilitarian Value Variable (X2) has a positive but not significant influence over the Repurchase Intention $(Z)$ with estimation value by $0.92 \%$ and $p$-value by 0.378 with positive direction.

5. Customer Satisfaction Variable $(Z)$ has a positive and significant influence over the Repurchase Intention ( $Y$ ) with estimation value by $86.9 \%$ and $p$-value by 0.000 with positive direction.

The most influential indicator towards Utilitarian value Variable (X1) is convenience with loading factor by 0.84 . The most influential indicator towards Hedonic Value variable is exploration with loading factor by 0.84 . Indicator as Expected has the biggest loading factor at Customer Satisfaction variable $(Z)$ by 0.89 and indicator of intention to engage in positive word-of-mouth has the biggest influence over the variable of Repurchase Intention ( $Y$ ) with a loading factor of 0.88 .

According to the conclusion drawn, so the suggestion can be provided is as follows:

1. For future researchers, it is better to add another variable of after and before customer satisfaction since the variable is influencing factors of customer satisfaction itself. In addition, the availability of more variable of post-customer satisfaction will be able to determine the impact of customer satisfaction itself. It is better to choose a product with longterm purchase as the object so that able to truly determine which one higher between utilitarian and hedonic value.

2. For website developer of Berrybenka.com, in accordance with research result for utilitarian value variable in which the highest factor is a convenience so that it is important for Berrybenka to be able to maintain the ease of use in the website, like the ease of payment, the ease of order, the ease of complaining delivery. The more ease the website uses, the more increase the utilitarian value obtained by the consumer and maintain consumer trust to make a transaction at Berrybenka. Furthermore, seen from hedonic value variable, the 
highest influential factor is that exploration indicator is suggested to be able to improve product types, especially up-to-date new products since Berrybenka customer is happy to do exploration towards Berrybenka products.

In relation to the impact of customer satisfaction which is repurchase intention, an intention to engage in positive word-of-mouth is an indicator having the highest influence of repurchase intention variable, so this indicator can be a reference to conduct the promotion. For example, facilitating customer to give a review to the product can add a discussion or commend column towards the product. In addition, berrybenka's product delivery neatness can be maintained or improved since according to the research result, packaging neatness gets highest mean value from the respondent. It means that Berrybenka' packaging is truly safe and neat so that the quality of the product is being up during the delivery process. In addition, it forces Berrybenka to maintain the benefit value of the product itself since on average the customer buys Berrybenka product more about the benefit than the prestige. Due to the number of new e-commerce is getting higher, Berrybenka should be more selective to select a brand which wants to join and maintain the variation of products available at Berrybenka.

\section{REFERENCES}

1. Babin, Barry J., andJill S Attaway. 2000. "Atmospheric As a Tool for Creating Value and Gaining Share of Customer ." Journal of Business Research 91-99.

2. Bridges, Eileen dan Renee Florsheim. 2008. "Hedonic and Utilitarian Shopping Goals: The Online Experience." Business Research 309-314.

3. Chiu, et al. 2012. "Understanding Customers Repeat Purchase Intentions in B2C ECommerce: The Roles of Utilitarian Value, Hedonic Value andPerceived Risk." Info System Journal 1-30.

4. CNN Indonesia. 2016. CNN Indonesia Teknologi. 27 April. Diakses Agustus 13, 2017. https://www.cnnindonesia.com/teknologi/20160427160429-185-126999/transaksi-ecommerce-indonesia-di-2016-ditaksir-rp394-triliun/.

5. Effendi, Singarimbun dan. 2011. Metode Penelitian Survai. Jakarta: LP3ES.

6. Engel, James F,. Blackwell, Roger D., Miniard, Paul D. 1994. Perilaku Konsumen . Jakarta: Binarupa Aksara.

7. Fernandez, Sanchez and Bonillo,Iniesta. 2007. "The concept of perceived value: a systematic review of the research." Marketing Theory 427-451.

8. Gholami, Saeed. Niousha Dehbini and Atefeh Shekari. 2016. "The Impact of Store Atmosphere on Hedonic and Utilitarian Shopping Values, Customer Satisfaction, and Customer Purchase Intention." Journal of Current Research in Science 305-311.

9. Hawkin, Del I and David LMothersbaugh. 2010. Consumer Behavior Building Marketing Strategy 11th edtion. New York: McGraw-Hill/Irwin.

10. Holbrook, Morris B. 2006. "Consumption Experince, Customer Value, and Subjective Personal Instrospection: An Illustrative Photographic Essay." Journal of Business Research 714-725.

11. Jakada, et al. 2016. "Consumer Satisfaction and Repurchase Intentions." Developing Country Studies 96-100.

12. Jogiyanto. 2011. Konsep dan Aplikasi Structural Equation Modeling. Yogyakarta: UPP STIM YKPN.

13. Keller, Philip Kotler and Lane. 2008. Manajemen Pemasaran Edisi 13 jilid 1. Jakarta: Erlangga.

14. Kotler, Philip and Amstrong,Gary. 2012. Principles of Marketing 14 Edition. New Jersey: Prentice Hall.

15. Kotler, Philip and Keller, Kevin Lane. 2009. Manajemen Pemasaran edisi 12. Jakarta: Indeks.

16. Levy, Michael and Weitz, Barton A. 2012. Retailing Management. New York: McGrawl-Hil Companies. 
17. Moon, Yun Ji. 2016. "Consumers Shopping Values for e-Satisfaction and e-Loyalty Moderating Effect of Personality." International Journal of u- and e-Service, Science, and Technology 331-342.

18. Sangadji, Etta Mamang., dan Sopiah. 2013. Perilaku Konsumen (Pendekatan Praktis). Yogyakarta: Penerbit Andi.

19. Solomon, Michael R. 2002. Consumer Behavior Buying, Having, and Being Fifth Edition. New Jersey: Prentice-Hall.

20. Solomon, Michael R. 2013. Consumer Behavior Buying, Havng, and Being. USA: Pearson.

21. Stathopoulou, A and Balabanis, G. 2016. "The effects of loyalty programs on customer satisfaction, trust, and loyalty toward." Journal of Business Research 1-8.

22. Sudaryono, Dr. 2016. Manajemen Pemasaran Teori \& Implementasi. Yogyakarta: ANDI.

23. Sugiati, et al. 2013. "The Role of Customer Value on Satisfaction and Loyalty (Study's on Hypermart Customer)." International Journal of Busness and Management Invention 6570.

24. Zeithaml, Valarie A. 1988. "Consumer Perceptions of Price, Quality and Value: A MeansEnd Models and Synthesis of Evidence." Journal of Mareting 2-22.

25. Zikmun, william G \& Babin, Barry J. 2013. Menjelajahi Riset Pemasaran Edisi 10, Buku 2. Penerjemah Diana Angelica, Hirson Kurnia. Jakarta: Salemba Empat.

26. Berrybenka. https://berrybenka.com/home/about.Diakses Agustus 13, 2017.

27. SWA. 2015. SWA. 15 Juni. Diakses Agustus 13, 2017. https://swa.co.id/swa/myarticle/hedonic-utilitarian-value-kombinasi-motivasi-konsumen-pada-grocery-shopping.

28. techinasia. 2016. techinasia internasional. 5 Februari. Diakses Agustus 13, 2017. https://id.techinasia.com/fokus-rakuten-indonesia-2016. 